University of Nebraska - Lincoln

DigitalCommons@University of Nebraska - Lincoln

\title{
Exploratory surveys in Australia and Asia for natural enemies of Old World climbing fern, Lygodium microphyllum: Lygodiaceae
}

John A. Goolsby

Anthony D. Wright

Robert W. Pemberton

Follow this and additional works at: https://digitalcommons.unl.edu/usdaarsfacpub

Part of the Agricultural Science Commons

Goolsby, John A.; Wright, Anthony D.; and Pemberton, Robert W., "Exploratory surveys in Australia and Asia for natural enemies of Old World climbing fern, Lygodium microphyllum: Lygodiaceae" (2003).

Publications from USDA-ARS / UNL Faculty. 347.

https://digitalcommons.unl.edu/usdaarsfacpub/347

This Article is brought to you for free and open access by the U.S. Department of Agriculture: Agricultural Research Service, Lincoln, Nebraska at DigitalCommons@University of Nebraska - Lincoln. It has been accepted for inclusion in Publications from USDA-ARS / UNL Faculty by an authorized administrator of DigitalCommons@University of Nebraska - Lincoln. 


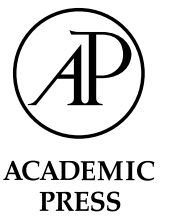

\title{
Exploratory surveys in Australia and Asia for natural enemies of Old World climbing fern, Lygodium microphyllum: Lygodiaceae
}

\author{
John A. Goolsby, ${ }^{\mathrm{a}, *}$ Anthony D. Wright, ${ }^{\mathrm{b}}$ and Robert W. Pemberton ${ }^{\mathrm{c}}$ \\ ${ }^{a}$ USDA-ARS, Australian Biological Control Laboratory, CSIRO Long Pocket Laboratories, 120 Meiers Rd., Indooroopilly, Qld. 4068, Australia \\ ${ }^{\mathrm{b}}$ CSIRO Entomology, Australian Biological Control Laboratory, 120 Meiers Rd., Indooroopilly, Qld. 4068, Australia \\ ${ }^{\mathrm{c}}$ USDA-ARS, Invasive Plant Research Laboratory, 3205 College Dr., Ft. Lauderdale, FL 33314, USA
}

Received 8 August 2002; accepted 4 March 2003

\begin{abstract}
Lygodium microphyllum, Old World climbing fern, is native to the wet tropics and subtropics of the Old World and an invasive weed in southern Florida. Exploration for natural enemies of this weed was conducted between 1997 and 2002 in Australia, China, India, Indonesia, Japan, Malaysia, New Caledonia, Singapore, Taiwan, Thailand, and Vietnam. Two species of mites and 20 insect species were collected. The eriophyid mite, Floracarus perrepae Knihinicki and Boczek, was the most widely distributed and appeared to cause significant damage to the plant over time. Several unique geographical genotypes of F. perrepae were identified. Other promising candidates for further research are the musotimine pyralid species, Neomusotima conspurcatalis Warren, Cataclysta camptozonale Hampson, Cataclysta sp. 2, and Musotima sp., all leaf-feeders, as well as the stem-borer Ambia sp. All of the herbivores collected, except the eriophyid, typically occurred at low field densities. The pyralid species may reach high densities and cause great damage in Florida in the absence of their co-evolved natural enemies. The mite $F$. perrepae shows the greatest potential for biological control based on field surveys and initial laboratory observations; however, future studies must identify mite genotypes that are best adapted to the invasive Florida form of the fern.
\end{abstract}

Published by Elsevier Science (USA).

Keywords: Floracarus; Fern-feeding moths; Invasive weed; Florida everglades; Foreign exploration; Biological control; Agent selection

\section{Introduction}

Lygodium microphyllum (Cav.) R. Br. (Lygodiaceae, Pteridophyta), the Old World climbing fern, is native to the Old World wet tropics and subtropics of Africa, Australasia, Asia, and Oceania (Pemberton, 1998). It is an aggressive invasive weed in moist habitats of southern Florida (Pemberton and Ferriter, 1998) and is classified as a Category I invasive species by the Florida Exotic Plant Pest Council (Langland and Craddock Burks, 1998). It was first found to be naturalized in Florida 1965, however, its explosive growth and rapid spread is now of increasing concern because of its dominance over native vegetation. Over 43,000 ha

\footnotetext{
${ }^{*}$ Corresponding author. Fax: +61-7-3214-2815.

E-mail address: john.goolsby@csiro.au (J.A. Goolsby).
}

$(107,000$ acres) are now infested in south Florida, a $150 \%$ increase from 1997 to 1999 (Pemberton et al., 2002). Pemberton and Ferriter (1998) predict the plant could spread further north in Florida into areas with low winter temperatures (USDA Plant Hardiness Zone 9b) (Cathey, 1990). Warm areas with high rainfall bordering the Gulf of Mexico and the Caribbean such as southern Louisiana, Yucatan of Mexico, Cuba, and Puerto Rico, would also be suitable for L. microphyllum. Herbicidal and mechanical controls are expensive, have limited effectiveness, and can cause considerable damage to non-target plants. Because L. microphyllum has become so invasive in south Florida, with a strong potential to spread further, a biological control program was initiated in 1997.

This paper covers exploration activities in Australia and Asia for biological control agents of L. microphyllum. Most of the information in this paper comes from 
surveys conducted in Australia and Southeast Asia from 1999 to 2002. L. microphyllum was found in a variety of subtropical and tropical habitats throughout its rangefrom $29^{\circ} \mathrm{S}$ in New South Wales, Australia, through Southeast Asia, to $24^{\circ} \mathrm{N}$ in the Guandong Province of China. This entire range was prioritized for exploration because the plant was common and not considered to be weedy; parts of the region are climatically similar to Florida; and a preliminary survey in Japan and Hong Kong in 1997 indicated the presence of herbivorous insects attacking Lygodium spp. The decision to explore this area was later bolstered by preliminary molecular evidence, which indicated that the invasive population in Florida was similar to collections from Australia and Southeast Asia and most distant from African populations (Goolsby and Pemberton, unpublished data). Populations of L. microphyllum were compared using gene sequences from the chloroplast intron using the methods of Thomson (2000). Although Lygodium is a worldwide genus, 15 of the 26 species occur in the Australian and Southeast Asian region (Garrison Hanks, 1998), including Lygodium flexuosum (L.) Sw. (Lygodiaceae), Lygodium reticulatum Schkuhr (Lygodiaceae), Lygodium japonicum (Thunb.) Sw. (Lygodiaceae), and Lygodium circinnatum (Burm.) S (Lygodiaceae). The high diversity of Lygodium species in this region should support more specialist herbivores than other areas. Pemberton did the first survey in Hong Kong and the later work in Japan and Taiwan. Goolsby focused his surveys on Australia, New Caledonia, and India and led the preliminary host screening. The Southeast Asian surveys were conducted by A.D. Wright.

\section{Materials and methods}

\subsection{Exploration}

Selection of search areas was guided by climate matching, habitat diversity, herbarium locality data, and knowledgeable specialists. The following countries were visited between September 1997 and March 2002: Australia, China, Japan, Indonesia, Malaysia, New Caledonia, Singapore, Taiwan, Thailand, and Vietnam. One preliminary survey was conducted in India in May 2002; it is reported at the end of this paper. CLIMEX software (Sutherst et al., 1999) was used to match the climate of West Palm Beach in South Florida with locations within the native range of $L$. microphyllum in Australia and Southeast Asia. Each survey at each site was documented with a unique Australian Biological Control Laboratory (ABCL) collection number and the following data were recorded: date, time spent searching, site coordinates, temperature, plant growth characteristics, and herbivore species. (This information can be ob- tained from ABCL, or through the USDA-ARS documentation Center that holds copies of ABCL annual reports.) Most locations were visited several times to account for seasonal effects on herbivore biodiversity. In addition to $L$. microphyllum, we surveyed $L$. reticulatum in Australia (21) and New Caledonia (9), and L. flexuosum (65) and L. japonicum (18) in Asia. Intensive monthly surveys were conducted from February 2000 to March 2002 at four field sites with L. microphyllum in southeast Queensland. Methods for collection included hand searches, sweeping, beating of foliage, and dissection of underground plant parts.

\subsection{Identification and characterization of arthropods}

Arthropods collected in the surveys were initially characterized with molecular tools and by comparison with specimens in the ABCL collection. Selected specimens were forwarded to cooperating systematists at the ARS Systematic Entomology Laboratory (SEL) (Beltsville, MD, USA), Queensland Museum (Brisbane, Queensland, Australia), Australian National Insect Collection (ANIC) (Canberra, ACT), and/or the Natural History of London (London, UK) (NHM) and the National Museum Prague, Czech Republic. Representatives of each insect and mite species collected were characterized at the CSIRO Entomology Molecular Diagnostic Laboratory, (Canberra, ACT). Multiple specimens were characterized in order to ensure consistency in the results. The D2 expansion domain of the 28S rRNA isolated from the nuclear genome was sequenced. The methods are those described by DeBarro et al. (2000). The numbers of individuals sequenced ranged from 1 to 30 depending on the quantity available. Whenever possible, we attempted to characterize individuals from each unique collection location and host plant. We used molecular characterization as a tool while taxonomic identifications were proceeding and as an interim method for assessing species diversity, identifying cryptic species, and matching immature stages with adults.

\subsection{Preliminary host-range testing}

A protocol was developed for preliminary host-range testing of the Pyralidae collected in the survey. Twelve plant species were tested in no-choice tests. Two pairs of newly emerged moths were placed inside a moistened plastic bag that enclosed a single, live fern leaf, or small group of pinnae. Adults were left in the bags until death or for five days, if eggs were visible. Larvae from these eggs were allowed to complete development on the live host plant. Test plants with adult moths and/or developing immatures were held at $25 \pm 2{ }^{\circ} \mathrm{C}$ with natural day lengths. 


\section{Results}

\subsection{Foreign exploration}

Lygodium microphyllum was found growing in a variety of habitats across its native range. In the states of Queensland and New South Wales in eastern Australia, L. microphyllum is common in the freshwater creeks and depressions of the coastal wetlands, often growing with Melaleuca quinquenervia (Cav.) S.T. Blake (Myrtaceae). In tropical north Queensland, L. microphyllum is sympatric with Lygodium reticulatum, but the latter prefers the upland rainforest habitats. In the monsoonal climate of far north Australia (Western Australia and Northern Territory), L. microphyllum is sympatric with Lygodium flexuosum and grows in the forest patches and along perennial creeks with abundant, slow-moving fresh water. In the Kimberley range of Western Australia, L. microphyllum is found growing in sheltered canyons near permanent springs. Across its range in Australia, L. microphyllum regrows vigorously following periodic bushfires, utilizing nutrients during a period of low herbivory. In Southeast Asia, L. microphyllum is common along the edges of lowland rainforests in peat soils, in coastal wetlands, and in wet, lateritic clay soils. Near the northern limit of its range in southern China, L. microphyllum is sympatric with $L$. japonicum and L. flexuosum. L. japonicum appears to be more competitive in the drier rocky soils, often found growing in a low prostrate form over whole hillsides. Throughout its range in Australia and Asia, the plant was never found to be more than a few meters tall and did not dominate its plant community.

Two mites and 20 insect species were collected feeding on L. microphyllum or related species (Table 1). The most commonly collected and geographically widespread herbivore was the eriophyid mite Floracarus perrepae Knihinicki and Boczek, followed by the pyralid moth Neomusotima conspurcatalis Warren. All of the herbivores on the list, except the eriophyid, typically occurred at low field densities. The total number of collections in which each species was found or showed evidence of its distinct damage was summarized for 513 field collections. F perrepae were collected from 172 (or $33.5 \%$ ) of the 513 samples (Fig. 1), as contrasted with an almost equal number of collections, 154 (or 30.0\%) from which no herbivores were recorded at all. In nearly half of the collections, 248, either no insect herbivores or only $F$. perrepae were collected. Several Lepidoptera species were collected and were represented in $41.4 \%$ of the samples (Fig. 1). The 22 herbivore species listed in Table 1 were collected over a three-year period, primarily in Australia and Southeast Asia.

The most promising species collected in the surveys were taken to ABCL for preliminary host-range testing. Closely related ferns, including related Lygodium species from the Neotropics, were tested (Table 2). The known biology, host range, and potential of these arthropods as biological control agents are discussed in the next section in the approximate order of value as biological control agents.

Comparison of climates using CLIMEX is summarized in Fig. 2. Based on the simple comparison of average monthly maximum and minimum temperatures, rainfall amounts, and rainfall pattern and relative humidity, eastern Australia, southern China, and southeast Africa had the best climatic matches with southern Florida, where selected agents from this survey are likely to be released.

\subsection{Herbivores collected in surveys}

\subsubsection{Floracarus perrepae (Acariformes: Eriophyidae)}

Floracarus perrepae Knihinicki and Boczek is the most widespread arthropod associated with $L$. microphyllum. It has been collected from locations in Australia, China, India, Indonesia, Malaysia, New Caledonia, Singapore, Sri Lanka, and Thailand. Knihinicki and Boczek (2002) included specimens from Australia, China, and New Caledonia in the original description of the species. Populations of this mite from five locations in Australia and Thailand, compared by sequencing the nuclear $28 \mathrm{~S}$ rRNA of D2 gene, had the same gene sequence. $F$. perrepae from China and New Caledonia showed 10 and two base-pair changes for the same gene region, respectively, which indicates there are unique genotypes of the mite within its distribution.

Floracarus perrepae appears to be tolerant of the wide range of climates found in the tropics and subtropics of the region. Populations of the mite are active year round. Mature females prefer the new sterile pinnae (the leaflets that do not produce spores) on actively growing plant tips for oviposition. Observations of newly formed leaf curls revealed up to five adults inside. Deformation in the leaf tissue appears to be induced by the feeding of the adult mite. Plant tissues become swollen and succulent as curling of the leaf begins. Attack on the leaf margin induces rolling, and on some pinnae, the whole margin may be affected. The leaf curls over downward and inward rolling on itself two-three times. Eggs are deposited and nymphs complete their development within the curl. Feeding by the adults and immatures leads to leaf necrosis and premature defoliation of L. microphyllum pinnae, gradually debilitating the plant over time. Eventually the mite-induced leaf necrosis and death equals the level of new growth. This 'steady state' is interrupted by the periodic bushfires in Australia. After a fire, the plant grows rapidly, stimulated by nutrients and apparent lack of suppression by the mite. Numerous field observations of L. microphyllum, after fire and without the mite, support the hypothesis that $F$. perrepae has a substantial impact on L. microphyllum (Goolsby, unpublished data). 
Table 1

Herbivores collected from Lygodium spp. in Asia and Australia

\begin{tabular}{|c|c|c|}
\hline Name (collection \#) & Collection locations & Host plant \\
\hline $\begin{array}{l}\text { Floracarus perrepae Knihinicki } \\
\text { and Boczek Acarina: Eriophyidae } \\
\text { (2001224) }\end{array}$ & $\begin{array}{l}\text { Australia, China, India, Indonesia, Malaysia, } \\
\text { New Caledonia, Singapore, Sri Lanka, } \\
\text { Thailand }\end{array}$ & $\begin{array}{l}\text { L. microphyllum (Cav.) R. Br. } \\
\text { L. reticulatum Schkuhr }\end{array}$ \\
\hline $\begin{array}{l}\text { Brevipalpis sp. Acarina: } \\
\text { Tenuipalpidae (2001566) }\end{array}$ & China, Singapore, New Caledonia & $\begin{array}{l}\text { L. microphyllum (Cav.) R. Br. } \\
\text { L. japonicum (Thunb.) Sw. }\end{array}$ \\
\hline $\begin{array}{l}\text { Neomusotima conspurcatalis } \\
\text { Warren Lepidoptera: Pyralidae } \\
\text { (1999228) }\end{array}$ & $\begin{array}{l}\text { Australia (Queensland, Northern Territory, } \\
\text { Western Australia), China, Indonesia, } \\
\text { Malaysia, Singapore, Thailand }\end{array}$ & L. microphyllum (Cav.) R. Br. \\
\hline $\begin{array}{l}\text { Cataclysta camptozonale Hampson } \\
\text { Lepidoptera: Pyralidae (2000223) }\end{array}$ & Australia (Queensland) & L. microphyllum (Cav.) R. Br. \\
\hline $\begin{array}{l}\text { Cataclysta sp. B Lepidoptera: } \\
\text { Pyralidae (1999231) }\end{array}$ & Australia (Queensland) & $\begin{array}{l}\text { L. microphyllum (Cav.) R. Br. } \\
\text { L. reticulatum Schkuhr }\end{array}$ \\
\hline $\begin{array}{l}\text { Musotima sp. Lepidoptera: } \\
\text { Pyralidae (199704) }\end{array}$ & Malaysia, Singapore, Thailand & L. microphyllum (Cav.) R. Br. \\
\hline $\begin{array}{l}\text { Neomusotima fuscolinealis } \\
\text { Yoshiyasu Lepidoptera: } \\
\text { Pyralidae (1997650) }\end{array}$ & Japan & L. japonicum (Thunb.) Sw. \\
\hline $\begin{array}{l}\text { Pyraustinae sp. Lepidoptera: } \\
\text { Pyralidae (2002566) }\end{array}$ & New Caledonia & L. microphyllum (Cav.) R. Br. \\
\hline $\begin{array}{l}\text { Ambia sp. Lepidoptera: Pyralidae } \\
\text { (2001449) }\end{array}$ & Singapore, Thailand & $\begin{array}{l}\text { L. microphyllum (Cav.) R. Br. } \\
\text { L. flexuosum (L.) Sw. }\end{array}$ \\
\hline $\begin{array}{l}\text { Callopistria sp. A Lepidoptera: } \\
\text { Noctuidae (2000686) }\end{array}$ & $\begin{array}{l}\text { Australia (Queensland), China, India, } \\
\text { Thailand }\end{array}$ & L. microphyllum (Cav.) R. Br. \\
\hline $\begin{array}{l}\text { Callopistria sp. B Lepidoptera: } \\
\text { Noctuidae (2000280) }\end{array}$ & Australia (Northern Territory) & L. microphyllum (Cav.) R. Br. \\
\hline $\begin{array}{l}\text { Callopistria sp. C. Lepidoptera: } \\
\text { Noctuidae (1998421) }\end{array}$ & Thailand & L. microphyllum (Cav.) R. Br. \\
\hline $\begin{array}{l}\text { Spodoptera litura }(\mathrm{F} .) \text { Lepidoptera: } \\
\text { Noctuidae }(1996201)\end{array}$ & Australia & L. microphyllum (Cav.) R. Br. \\
\hline $\begin{array}{l}\text { Archips machlopis Meyrick } \\
\text { Lepidoptera: Tortricidae (1998421) }\end{array}$ & Malaysia, Singapore, Thailand & L. microphyllum (Cav.) R. Br. \\
\hline $\begin{array}{l}\text { Neostromboceros albicomus } \\
\text { (Konow) Hymenoptera: } \\
\text { Tenthridinidae (2001429) }\end{array}$ & Malaysia, Singapore, Thailand, Vietnam & $\begin{array}{l}\text { L. microphyllum (Cav.) R. Br. } \\
\text { L. flexuosum (L.) Sw. }\end{array}$ \\
\hline $\begin{array}{l}\text { Metriona sp. Coleoptera: } \\
\text { Chrysomelidae (1999246) }\end{array}$ & $\begin{array}{l}\text { Australia (Northern Territory, } \\
\text { Western Australia) }\end{array}$ & L. microphyllum (Cav.) R. Br. \\
\hline $\begin{array}{l}\text { Endelus bakerianus Obenberger } \\
\text { Coleoptera: Buprestidae (1999440) }\end{array}$ & Singapore, Thailand & L. microphyllum (Cav.) R. Br. \\
\hline $\begin{array}{l}\text { Manobia sp. Coleoptera: } \\
\text { Chrysomelidae (1999432) }\end{array}$ & Thailand & L. flexuosum (L.) Sw. \\
\hline $\begin{array}{l}\text { Lophothetes sp. Coleoptera: } \\
\text { Apionidae (1998550) }\end{array}$ & Palau & L. microphyllum (Cav.) R. Br. \\
\hline $\begin{array}{l}\text { Acanthuchus trispinifer (Fairmaire) } \\
\text { Hemiptera: Membracidae (1999202) }\end{array}$ & Australia (Queensland, Northern Territory) & L. microphyllum (Cav.) R. Br. \\
\hline $\begin{array}{l}\text { Pseudococcus longispinus } \\
\text { (Targioni-Tozzetti) Homoptera: } \\
\text { Pseudococcidae (2000285) }\end{array}$ & Australia (Queensland) & L. microphyllum (Cav.) R. Br. \\
\hline $\begin{array}{l}\text { Octothrips lygodii Mound } \\
\text { Thysanoptera: Thripidae (2000677) }\end{array}$ & China, Singapore, Thailand & $\begin{array}{l}\text { L. microphyllum (Cav.) R. Br. } \\
\text { L. flexuosum (L.) Sw. L. japonicum } \\
\text { (Thunb.) Sw. }\end{array}$ \\
\hline
\end{tabular}




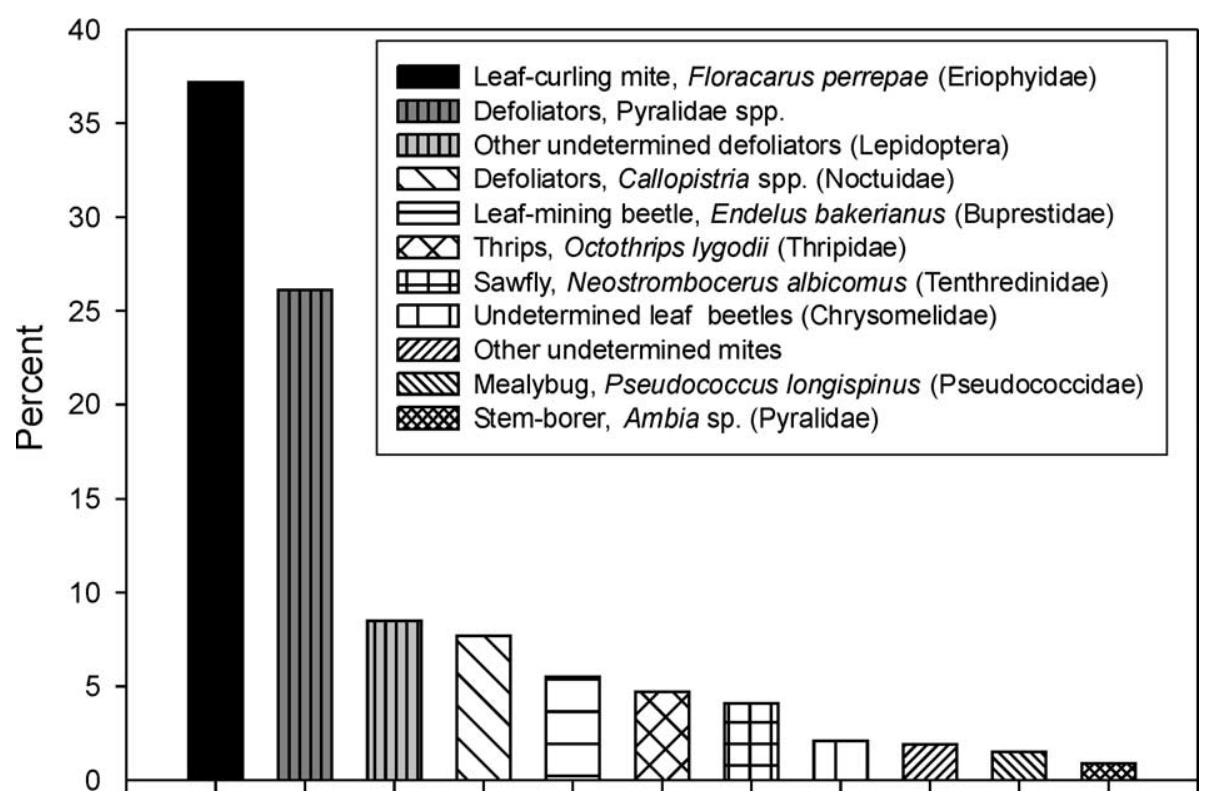

Fig. 1. Relative abundance of herbivores in field collections, based on $100 \%$ of the number of herbivores.

Table 2

List of species tested in Australia

\begin{tabular}{|c|c|c|}
\hline Family & Plant species & Comments \\
\hline Lygodiaceae & Lygodium microphyllum (Cav.) R. Br. & Australian form \\
\hline Lygodiaceae & Lygodium microphyllum (Cav.) R. Br. & Florida form \\
\hline Lygodiaceae & Lygodium flexuosum $(\mathrm{L}.) \mathrm{Sw}$. & Native to Australia and Asia \\
\hline Lygodiaceae & Lygodium japonicum (Thunb.) Sw. & Native to Australia and Asia, weed in USA \\
\hline Lygodiaceae & Lygodium reticulatum Schkuhr & Native to Australia and New Caledonia \\
\hline Lygodiaceae & Lygodium oligostachyum (Willdenow) Desv. & Native to West Indies \\
\hline Lygodiaceae & Lygodium palmatum (Bernhardi) Swartz & Native to temperate $\mathrm{N}$. America \\
\hline Lygodiaceae & Lygodium venustrum $\mathrm{Sw}$ & Native to West Indies, Central and South America \\
\hline Schizaeaceae & Schizaea bifida Willdenow & In same habitat in Australia \\
\hline Schizaeaceae & Anemia adiantifolia (L.) Swartz & In same habitat in Florida \\
\hline Aspleniaceae & Asplenium nidus L. & Ornamental \\
\hline Aspleniaceae & Asplenium scolopendrium $\mathrm{L}$. & Ornamental \\
\hline Blechnaceae & Blechnum indicum Burm. f. & In same habitat in Australia \\
\hline Cyathaceae & Cyathea cooperi (F.J. Muell.) Domin & Ornamental, native to Australia \\
\hline Dennstaediaceae & Hypolepis muelleri N.A. Wakoef & In same habitat in Australia \\
\hline Dennstaediaceae & Pteridium aquilinum (L.) Kuhn & Wide-spread, native to south Florida \\
\hline Dryopteridaceae & Nephrolepis biserrata (Swartz) Schott & Native to Florida, ornamental \\
\hline Dryopteridaceae & Polystichum acrostichoides (Michaux) Schott & Native to Florida \\
\hline Dryopteridaceae & Rumohra adiantiformis (G. Forst.) Ching & Important florist fern, ornamental \\
\hline Gleicheniaceae & Sticherus flabellatus (R. Br.) H. St. John & In same habitat in Australia \\
\hline Lycopodiaceae & Lycopodiella cernua (L.) Pic. Serm. & Native to Florida and Australia \\
\hline Ophioglossum & Ophioglossum petiolatum L.f. & Native to Florida and Australia \\
\hline Osmundaceae & Osmunda regalis $\mathrm{L}$. & Native to Florida, ornamental \\
\hline Parkeriaceace & Ceratopteris thalictroides (L.) Brongniart & In same habitat in Australia \\
\hline Polypodiaceae & Phlebodium aureum (L.) J. Smith & Native to Florida, ornamental \\
\hline Polypodiaceae & Platycerium hillii $\mathrm{T}$. Moore & Ornamental, native to Australia \\
\hline Psilotaceae & Psilotum nudum (L.) Palisot de Beauvois & Native to Florida and Australia \\
\hline Pteridaceae & Acrostichum speciosum Willdenow & Native to Australia \\
\hline Pteridaceae & Adiantum capillus-veneris $\mathrm{L}$. & Native to Australia and USA \\
\hline Salviniaceae & Salvinia molesta D.S. Mitchell & Weed in Australia and USA \\
\hline Selaginellaceae & Selaginella emmeliana F. Schmitz and M. Moller & Primitive fern ally \\
\hline Thelypteridaceae & Thelypteris patens (Swartz) Small & Native to south Florida \\
\hline
\end{tabular}

The field host range of this species appears to be limited to $L$. microphyllum and $L$. reticulatum. Field collections of L. japonicum, L. flexuosum, and
L. circinnatum do not show any evidence of this eriophyid mite. $F$. perrepae appears to be an excellent candidate for biological control based on its ability to 


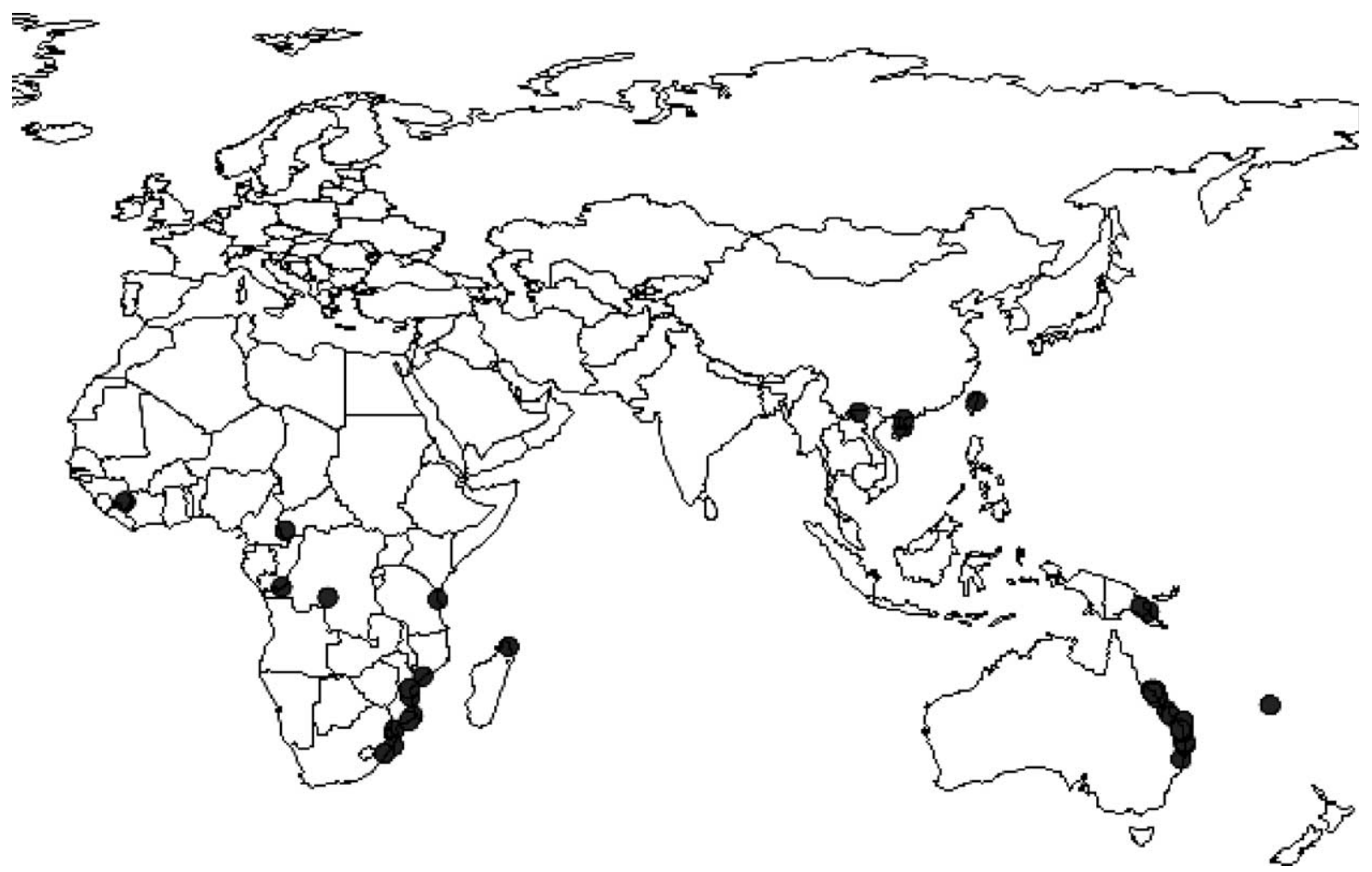

Fig. 2. A CLIMEX map showing the similarity of West Palm Beach, Florida with locations in the native range of L. microphyllum. Dots represent a $70 \%$ climate match or better.

suppress plant growth and its narrow host range. However, recent observations of Queensland population of the mite indicated that the mites performed poorly on the Florida form of $L$. microphyllum compared to the Queensland form of L. microphyllum (Goolsby, unpublished data). This suggests the genotypes may be host races of the mite. Searches for a $F$. perrepae race or biotype that is better suited to the Florida genotype of L. microphyllum are underway.

\subsubsection{Brevipalpis sp. (Acariformes: Tenupalpidae)}

Brevipalpis sp. was collected from L. microphyllum and L. japonicum in Australia, China (Hong Kong), New Caledonia, and Singapore. Feeding by the mites on the surface of the leaves caused a stippling effect. The damage to the plant appeared to be very minor. In New Caledonia we observed a similar stipling effect on a species of sword fern, Nephrolepis sp., that was growing with L. microphyllum. Due to its potentially broad host range and minor effect on the plant, this species was not considered further as a biological control agent.

\subsubsection{Neomusotima conspurcatalis (Lepidoptera: Pyral- idae)}

Neomusotima conspurcatalis Warren has been collected throughout the range of $L$. microphyllum in Southeast Asia and Australia, except subtropical Queensland and New South Wales. Representatives from throughout its geographic range were compared using molecular diagnostic methods, which showed an exact match between the specimens from Australia, China, and other parts of Southeast Asia. It is not known why this species is not present in subtropical Queensland and New South Wales. It is common in other subtropical parts of Asia, including southern China, where winter minimum temperatures are just as cold as in subtropical Australia. The dry tropics between Townsville and Mackay, Queensland, from which L. microphyllum is absent, may act as biogeographic barrier that limits the southern distribution of the moth.

Adults of $N$. conspurcatalis are dark brown with distinctive lighter colored 'boomerang' shaped markings on their forewings, which are approximately $6 \mathrm{~mm}$ long. Eggs are yellow and laid singly or in small clusters, mostly on the new growth. Larvae are green with setae not visible to the naked eye. Early instar larvae skeletonize L. microphyllum leaves, while fourth-instar larvae consume entire leaves. $N$. conspurcatalis pupates above ground on the plant in a concealed location. The developmental period from egg to adult at $25^{\circ} \mathrm{C}$ is approximately 25 days. Natural populations remain at very low levels, sometimes at undetectable levels, throughout the year. This was the most frequently collected insect species in the survey. Some collections were made from remote stands and isolated patches of new growth following extensive bush fires, which suggests good dispersal ability. 
In preliminary host range testing, complete development occurred only on four of the six Lygodium spp. (Table 3). Females were induced to lay eggs on eight fern species outside the Lygodium genus, but none of the larvae lived past the first instar. The preliminary testing suggested that $N$. conspurcatalis may be a genus-level specialist. Neither the moth nor its distinctive feeding damage was observed in the field on $L$. japonicum, $L$. reticulatum, $L$. flexuosum, or $L$. circinatum. The lack of field use on these Lygodium species is good evidence that the field host-range of this insect may be limited to relatively few species in the genus. This species is a good candidate agent for biological control of L. microphyllum.

\subsubsection{Cataclysta camptozonale (Lepidoptera: Pyralidae)}

Cataclysta camptozonale Hampson is distributed from subtropical southeast Queensland and northern New South Wales. The climate in southeast Queensland and northern New South Wales is cool-subtropical. This area rarely experiences freezing temperatures, but winter minimums normally fall to $3-5^{\circ} \mathrm{C}$ several nights each year. C. camptozonale from this part of its range may be better adapted to the cool winters of south Florida.
Cataclysta is not the correct genus for this species. Cataclysta is in the subfamily Nymphulinae, which includes mostly species feeding on aquatic plants, whereas C. camptozonale has been assigned to the Musotiminae, which includes mostly fern-feeding species. A new genus will be described by Alma Solis, USDA-ARS, Systematic Entomology Laboratory, Beltsville, MD, and ShenHorn Yen, Department of Biology, Imperial College at Silwood Park, Ascot, England which will include C. camptozonale and Cataclysta sp. B.

Adults are cream colored with light brown bands and darker speckles along the margins of the hind wings and forewings that are approximately $8 \mathrm{~mm}$ in length. Eggs are yellow and laid singly or in small clusters, mostly on the new growth. Larvae are green with no visible setae. Early instar larvae skeletonize L. microphyllum leaves, with fourth instar larvae consuming entire leaves. $C$. camptozonale pupate above ground on the plant in a concealed location. The approximate developmental period from egg to adult at $27^{\circ} \mathrm{C}$ is 21 days. Natural populations remain at very low, sometimes at undetectable levels throughout the year. A localized outbreak near Logan in southeast Queensland occurred in April 2000. High densities of the larvae were noted

Table 3

Preliminary host-range testing of three Pyralidae ${ }^{\mathrm{a}}$

\begin{tabular}{|c|c|c|c|}
\hline Plant species & Neomusotima conspurcatalis Warren & Cataclysta camptozonale Hampson & Musotima sp. \\
\hline Lygodium microphyllum (Cav.) R. Br. (QLD) & ++ & ++ & + \\
\hline Lygodium microphyllum (FL) & ++ & ++ & ++ \\
\hline Lygodium japonicum (Thunb.) Sw. & + & + & ++ \\
\hline Lygodium palmatum (Bernhardi) Swartz & + & ++ & + \\
\hline Lygodium reticulatum Schkuhr & NT & ++ & NT \\
\hline Lygodium oligostachyum (Willdenow) Desv. & NT & 0 & NT \\
\hline Anemia adiantifolia (L.) Swartz & NT & 0 & 0 \\
\hline Schizaea bifida Willdenow & NT & 0 & NT \\
\hline Asplenium nidus L. & 0 & 0 & 0 \\
\hline Asplenium scolopendrium $\mathrm{L}$. & NT & 0 & NT \\
\hline Cyathea cooperi (F.J. Muell.) Domin & 0 & 0 & 0 \\
\hline Hypolepis muelleri N.A. Wakoef & NT & 0 & NT \\
\hline Pteridium aquilinum $($ L.) Kuhn & 0 & 0 & 0 \\
\hline Nephrolepis biserrata (Swartz) Schott & 0 & 0 & 0 \\
\hline Polystichum acrostichoides (Michaux) Schott & NT & 0 & NT \\
\hline Rumohra adiantifolormis (G. Forst.) Ching & 0 & 0 & 0 \\
\hline Sticherus flabellatus (R. Br.) H. St. John & NT & 0 & NT \\
\hline Lycopodiella cernuum (L.) Pic. Serm. & NT & 0 & NT \\
\hline Ophioglossum petiolatum L.f. & NT & 0 & NT \\
\hline Osmunda regalis $\mathrm{L}$. & 0 & 0 & 0 \\
\hline Ceratopteris thalictroides (L.) Brongniart & NT & 0 & NT \\
\hline Phlebodium aureum (L.) J. Smith & 0 & 0 & 0 \\
\hline Platycerium hillii $\mathrm{T}$. Moore & NT & 0 & NT \\
\hline Psilotum nudum (L.) Palisot de Beauvois & NT & 0 & NT \\
\hline Acrostichum speciosum Willdenow & NT & 0 & NT \\
\hline Adiantum capillus-veneris L. & 0 & 0 & 0 \\
\hline Salvinia molesta D.S. Mitchell & 0 & 0 & 0 \\
\hline Selaginella emmelliana F. Schmitz M. Moller & NT & 0 & NT \\
\hline Thelypteris patens (Swartz) Small & NT & 0 & NT \\
\hline
\end{tabular}

${ }^{\mathrm{a}}$ No-choice tests were conducted, (++) indicates full development, (+) marginal development, (0) no development, NT, not tested; QLD, Queensland; FL, Florida. 
defoliating entire patches of L. microphyllum. Searches were conducted on two other fern species in the same habitat; Blechnum indicum Burm. f. and Hypolepis mueller N.A. Wakoef, and no C. camptozonale were observed.

Host-range testing indicated that C. camptozonale is a specialist at the genus level (Table 3). Females were induced to lay eggs on nine fern species outside the $L y g$ odium genus. In all cases the first-instar larvae died shortly after hatching. In most instances it was observed that the larvae attempted to feed on the test plant but did not find it suitable. In the field, the host range appears to be limited to L. microphyllum and L. reticulatum. Both species are sympatric in north Queensland in the wet tropics. No other Lygodium species are present in the range of C. camptozonale. However, based on the potential cold hardiness and its narrow host range, this species appears to be a good candidate agent for biological control.

\subsubsection{Cataclysta sp. B (Lepidoptera: Pyralidae)}

Cataclysta sp. B was collected from two sites in the wet tropics of north Queensland from both L. microphyllum and L. reticulatum. Adults are very similar in appearance to $C$. camptozonale and distinguished by observation of the female genitalia (Yen and Solis, Imperial College, Ascot, UK and USDA-ARS, Washington, DC, unpublished data). Its biology is similar to that of C. camptozonale. It may also be a good candidate for biological control.

\subsubsection{Musotima sp. (Lepidoptera: Pyralidae)}

Musotima sp. has been collected in lowland tropical Malaysia, Singapore, and southern Thailand. Specimens from these areas had identical molecular profiles. The distribution of this species appears to be limited to the wet tropics of Southeast Asia. It has a similar biology and developmental time as $N$. conspurcatalis.

Musotima is not the correct genus for this species. A new genus will be described by Alma Solis (USDAARS) and Shen-Horn Yen (Imperial College at Silwood Park, Ascot, UK), which will include this species.

Preliminary host-range testing indicates that Musotima sp. is a genus-level specialist, as oviposition and complete development occurred only on Lygodium species (Table 3). Females were induced to lay eggs on four fern species outside the Lygodium genus, but none of the larvae survived past the first instar. In the field, $L$. japonicum, L. flexuosum, and L. circinatum were surveyed but no Musotima sp. were collected, nor were any signs of its distinctive damage visible. This may be evidence that the field host-range of this insect may be more narrowly specific below the genus level. This species is a good candidate agent for biological control of $L$. microphyllum, especially in tropical parts of south Florida along the east coast.

\subsubsection{Neomusotima fuscolinealis (Lepidoptera: Pyrali-} dae)

Neomusotima fuscolinealis Yoshiyasu was reared from $L$. japonicum in Japan, in Tokyo and the Mie Prefecture near Nagoya. Although this Japanese moth was previously known, its host plant was not (Yoshiyasu, 1985). It is a foliage-feeder and is believed to have a similar biology to $N$. conspurcatalis. The moth is probably a narrow specialist like other Lygodium feeding pyralids. $N$. fuscolinealis larvae were observed to feed upon and defoliate L. japonicum plants growing in the fern collection of the University of Tokyo Botanical Gardens, but no larvae or characteristic feeding damage (skeletonized leaves, silk webs with frass) were found on other fern species. Its molecular profile is distinct from those of the other Pyralidae in this survey. This temperate species may be useful if a biological control program is initiated for $L$. japonicum, if it is unable to use the temperate North American L. palmatum as a host.

\subsubsection{Ambia sp. (Lepidoptera: Pyralidae)}

An unknown stem-boring Ambia species was collected from L. microphyllum in Singapore and L. flexuosum in Thailand. Molecular profiles are considerably different for Ambia sp. from both locations and host plants, which most likely indicates the existence of two species. Although very similar in appearance, the Thai moth's white forewing is 8 -mm long and patterned with black, which creates a strong resemblance to a crab-like spider, which it may mimic. The larvae can cause considerable damage to L. microphyllum as they tunnel in stems, eventually causing death of the shoot distal to the larval feeding. Although uncommon in the field, the sight of a long, dead shoot amongst undamaged healthy foliage was impressive and indicated the potential damage that could be caused by a large population of this pyralid. Larvae have a terminal, sclerotized plate, presumably to block the tunnel or the entry/exit hole in the stem. Stem damage has also been observed on L. flexuosum in Singapore. This species has been difficult to bring into culture for host-specificity testing because of its rarity. It is a good candidate agent for biological control because of the unique damage it causes to L. microphyllum.

\subsubsection{Pyraustinae gen. nov. sp. nov. (Lepidoptera: Pyralidae)}

An unknown foliage-feeding species of Pyraustinae was collected from L. microphyllum in New Caledonia. The adults are pale fuscous brown, with forewings approximately $7 \mathrm{~mm}$ in length. The larvae are green, skeletonizing leaves as early instars and consuming whole leaves in the later instars. At one site near Noumea in Province Sud, New Caledonia, this species was very abundant on two occasions, causing considerable 
damage to L. microphyllum. Collections were made during the day (mid-morning) and at night $1-2 \mathrm{~h}$ after sunset. Larvae were inconspicuous or hiding during the day and feeding on the vines on trees at night, suggesting that they appear to be nocturnal feeders. Many more larvae were collected in the night surveys. We did not collect any of the pyraustine larvae on the foliage of other ferns during day or night searches at this location, indicating that this species may have a narrow host range.

\subsubsection{Callopistria spp. (Lepidoptera: Noctuidae)}

Several species of Callopistria have been collected from L. microphyllum in Australia and Asia. Molecular diagnostics indicates three putative species: 'A' type from Australia (Queensland), China, India and Thailand; 'B' type from Australia (Northern Territory and Western Australia), and ' $\mathrm{C}$ ' type from Thailand. All the known Callopistria spp. are fern-feeders, and most are thought to be generalist fern-feeders (Robinson, London Museum of Natural History, London, UK, personal communication), but little is known about the host range of the species collected from L. microphyllum. An American species, Callopistria floridensis Guenée occurs in the same habitat with L. microphyllum in Florida (Buckingham and Pemberton, USDA-ARS, Gainesville, Florida, unpublished data) and is known to be a generalist fern feeder and a pest of cultivated ferns in Florida (Leibee and Stamps, 1999). Limited testing of one Callopistria sp. in Australia suggested the possibility of greater specialization of Lygodium-feeding species encountered in our surveys. The presence of a congeneric Callospistria in Florida probably also means the presence of parasitoids of Callopistria which might influence the abundance of Callopistria spp. introduced for biological control of L. microphyllum.

3.2.10.1. Callopistria sp. A. Callopistria sp. A has been collected from L. microphyllum near Cairns, north Queensland, Australia; Hong Kong and Hainan, southern China; southern Tamil Nadu, India and several locations throughout Thailand. Molecular profiles for specimens from these locations are identical. The adult is dark grayish brown with a mosaic of black, light gray, and brown patches on its forewings. The forewings are $12 \mathrm{~mm}$ in length with distinctive light gray bands extending to the inner margins. The larvae are green as early instars, becoming pink in the last instar. Early instars skeletonize leaves and later consume whole leaves as they mature. Clusters of leaves with missing pinnae in a 'fish bone' pattern are characteristic of the larval feeding damage. This distinctive damage can be used to locate 'hot spots' of Callopistria.

3.2.10.2. Callopistria sp. B. Callopistria sp. B has been collected from the Kimberly Region near Kununurra in
Western Australia and Litchfield National Park in Northern Territory. Molecular profiles are the same for both populations. The adults and immatures have a similar biology and appearance to Callopistria sp. A. The population from Western Australia was tested in two choice experiments. In the first experiment the $L$. microphyllum plus other non-target test species, Anemia adiantifolia (L.) Swartz, Cyathea cooperi (F.J. Muell.) Domin, Thelypteris patens (Swartz) Small, and Adiantum capillus-veneris $\mathrm{L}$. were exposed to adult moths. In the second experiment the same non-target test species were caged without L. microphyllum. In the first experiment, large numbers of eggs were laid on L. microphyllum. Larvae in this test completely consumed the $L$. microphyllum plant, but no damage was observed on the other species. In the second experiment, eggs were laid on $C$. cooperi, but no development was observed. Further testing is needed to determine the host range of this species.

3.2.10.3. Callopistria sp. C. Callopistria sp. C has only been collected once from L. microphyllum in Thailand. The adults have a similar appearance to Callopistria sp. A. Further testing is needed to determine the host range of this species.

\subsubsection{Spodoptera litura (Lepidoptera: Noctuidae)}

Spodoptera litura (F.) has been collected from $L$. microphyllum in southeast Queensland. This species is highly polyphagous and is frequently a greenhouse pest at CSIRO research facilities in Indooroopilly, Queensland. It has also been reared from field collections on Melaleuca quinquenervia (Myrtaceae). This armyworm is a well-known pest of row crops, trees, and even aquatic plants in Asia (Robinson et al., 2001). This species is not being considered as a biological control agent because of its broad host range.

\subsubsection{Archips machlopis (Lepidoptera: Tortricidae)}

Archips machlopis Meyrick were collected from $L$. microphyllum at six sites in southern Thailand. This moth belongs to a species-group that is known to be polyphagous (Robinson et al., 2001). Therefore, it is not being considered for further testing.

\subsubsection{Neostromboceros albicomus (Hymenoptera: Ten- thridinidae)}

Neostromboceros albicomus (Konow) was collected from L. microphyllum in Thailand and Vietnam and from L. flexuosum in Thailand. Neostromboceros albicomus from L. flexuosum and L. microphyllum may represent two separate species. Specimens apparently identical to the L. flexuosum sawfly ( $N$. albicomus), but collected from L. microphyllum, were shown by DNA comparisons to be slightly different. Sequencing of the 
D2 gene revealed a two base-pair difference. It is not known if this amount of genetic difference indicates that the two types are separate species. However, each type develops more readily on its original host species, $N$. albicomus A on L. flexuosum, and $N$. albicomus B on $L$. microphyllum. Smith et al. (2002) described specimens from both host plants as $N$. albicomus.

Adult N. albicomus are black and appear sluggish on the host plant. Females lay conspicuous yellow eggs, singly and in clusters, on the new growth. Larvae are bright yellow with an iridescent blue head and tip of abdomen. Local populations can reach fairly high densities, defoliating patches of $L$. microphyllum and $L$. flexuosum. Pupation occurs in the soil, which may provide protection from periodic wildfires. It appears from field surveys that ' $\mathrm{B}$ ' form is specific to L. microphyllum. The apparently narrow host range of this insect and its unique biology as a sawfly make it a good candidate agent for biological control.

\subsubsection{Manobia sp. (Coleoptera: Chrysomelidae)}

The flea beetle, Manobia sp., was regularly collected from L. flexuosum in northern Thailand. Adults were observed feeding on the leaf margins of L. flexuosum. While rearing on L. microphyllum was not successful, the beetle reared well on $L$. japonicum. In quarantine, larvae appeared to be feeding on the roots and rhizome of $L$. japonicum. L. japonicum is reported to be weedy in central and north Florida and areas of the southern USA through to east Texas. If a biological control program is initiated for L. japonicum, this agent could be valuable if it cannot use the North American native $L$. palmatum.

\subsubsection{Endelus bakerianus (Coleoptera: Buprestidae)}

This leaf-mining beetle, Endelus bakerianus Obenberger, was collected in Singapore and Thailand from L. microphyllum. Females oviposit on the leaf margins of new growth and the larvae tunnel between leaf surfaces, completing development in one subpinna (leaflet). Pupation occurs in the leaf tissue. The length of the life cycle is not known. Although this species has only been collected from L. microphyllum, its field host range is not known. This species remains a candidate agent for biological control, but more information is needed on its potential for damage and its host range.

\subsubsection{Lophothetes sp. (Coleoptera: Apionidae)}

A defoliating species of Lophothetes was collected from L. microphyllum in Palau in the Pacific (V. Brancatini, CSIRO, Indooroopilly, Queensland, oral communication). Only adults were collected; no immatures were observed. Additional collections and testing are needed to determine its identity and host association with L. microphyllum.
3.2.17. Acanthuchus trispinifer (Hemiptera: Membracidae)

Acanthuchus trispinifer (Fairmaire) was collected in southeast Queensland and in the Northern Territory from L. microphyllum. Although some feeding damage was associated with adults, no reproduction was observed. Adults held in cages with whole plants lived for several weeks, but did not oviposit. L. microphyllum does not appear to be a primary host for A. trispinifer.

\subsubsection{Pseudococcus longispinus (Hemiptera: Pseudo- coccidae)}

Longtailed mealybug, Pseudococcus longispinus (Targioni-Tozzetti), is highly polyphagous and a known pest of citrus and ornamentals (Clausen, 1978). This is the first record of this mealybug on L. microphyllum. This species is not being considered for further testing.

\subsubsection{Octothrips lygodii (Thysanoptera: Thripidae)}

Octothrips lygodii Mound was collected from L. microphyllum, L. flexuosum, and L. japonicum in China, Thailand, and Singapore (Mound, 2002). It is also described from Indonesia and Japan. This thrips is an extremely common herbivore in Southeast Asia, sometimes occurring in large numbers and being very damaging to L. microphyllum. The host range of $O$. lygodii collected in this survey is unknown.

\subsection{Survey in India and Sri Lanka}

Preliminary surveys for herbivores were conducted in southern India and Sri Lanka in 2002. The west coast of Tamil Nadu from Chennai (Madras), over to wet, tropical Kerala and the highlands of the southern Ghat Mountains were explored. Two Lygodium species were found in this region, L. flexuosum and L. microphyllum, with the former being more common. A fern-feeding moth, Callopistria sp. A, was collected from two locations in Tamil Nadu along with the eriophyid, $F$. perrepae. In Sri Lanka, only $F$. perrepae was observed.

\section{Discussion}

Three fern species have been previously targeted in biological control programs: Pteridium aquilinum (L.) Kuhn (Kirk, 1977), Salvinia molesta Mitchell (Room et al., 1981), and Azolla filiculoides Lamarck (Hill, 1998). P. aquilinum, bracken fern, is a weed of agricultural and environmental areas (Kirk, 1977). It produces an array of arsensic-based compounds, which are both toxic and carcinogenic to cattle (Kirk, 1977). Exploration for agents of $P$. aquilinum was conducted over a two-year period in Papua New Guinea where the diversity of climates was expected to yield agents suitable for release in the UK and Australia. Kirk (1977) found 
31 herbivores associated with bracken in the middle to higher elevations $(450-3300 \mathrm{~m})$ of its range in Papua New Guinea. However, worldwide more than 400 species of insects are recorded from $P$. aquilinum (Balik et al., 1978). None of the insect species collected from Papua New Guinea were released in the UK because of the concerns that biological control agents should not be released against a native plant species.

The second biological control program involved the aquatic fern $S$. molesta, giant salvinia. This program is now recognized as an example of one of the most successful examples of biological control efforts against a weed (Room et al., 1981). Three years of exploration were conducted in this plant's native range in southeastern Brazil by Forno (1983) who documented 11 insect species feeding on $S$. molesta, with an additional 13 species believed to be herbivores but not confirmed, including Cyrtobagous salviniae Calder and Sands (Sands, 1983). The latter has successfully controlled the weed everywhere it has been released, including locations in Australia, Africa, and Asia (Forno, 1987; Julien et al., 2002; Sands et al., 1986).

The third fern species targeted for biological control is $A$. filiculoides, red water fern, which is native to South America and established in South Africa, where it is widespread, causing severe degradation of aquatic ecosystems (Hill, 1998). The weevil, Stenopelmus rufinasus Gyllenhal was released in South Africa to control red water fern, and initial results are promising (Hill, 1999). This weevil was originally collected from Azolla caroliniana Willd. in Florida. A short term, 9-day search in Argentina, the native range of $A$. filculoides, identified 3 herbivore species, including the allied weevil species Stenopelmus brunneus (Hustache).

The exploration efforts for the $P$. aquilinum and $S$. molesta program were similar, with 31 and 24 species of herbivores collected, respectively. The senior author queried the explorers of the previous three biological programs targeting ferns. All indicated that fern herbivores were rarely abundant in their native habitat, and that frequent searches were necessary to assess the species diversity.

The results of exploration for L. microphyllum agents follows the same trend that intensive studies are needed to assess their arthropod herbivore fauna. The number of herbivores collected in our study (21) is similar to the numbers collected in two of the three previous biological control programs targeting ferns. In field surveys, we found that because the insect herbivores of $L$. microphyllum occurred at such low density and were frequently below detection levels for long periods of time, frequent site-visits over several years were needed to collect the maximum number of herbivore species. This is quantified by the fact that in more than a quarter $(26.3 \%)$ of the surveys, no herbivores were observed at all. Fig. 1 depicts the proportions of insects and mites collected from our surveys, which fall into the orders, Acarifomes, Lepidoptera, Coleoptera, Hymenoptera, Hemiptera, and Thysanoptera. In a review of the literature, Balik et al. (1978) found 420 arthropod species were recorded from ferns, of which the majority of insect herbivores were from the orders Coleoptera, Hymenoptera, Lepidoptera, and Hemiptera. Our survey tends to agree with Balik et al. (1978), but we found that Acarina and Lepidoptera formed the majority of herbivores collected, with Coleoptera and Hemiptera being by comparison under-represented. Lepidoptera species were represented in $43.2 \%$ of the collections. Of the Lepidoptera collected, $25 \%$ were species of Callopistria, a genus of specialist fern-feeders in the family Noctuidae. Of the remaining Lepidoptera, $75 \%$ were of fern-feeding Pyralidae, in the subfamily Musotiminae. This is similar to the other fern biological control programs, in which a total of five species of Pyralidae were collected. Of these five, only one, Samea multiplicalis Guenee (Pyraustinae), had sufficient host specificity to warrant release. In regard to Lygodium, all of the Musotiminae species appear to be genus-level specialists (Table 3 ). This suggests that the fern-specializing Musotiminae species may have a long evolutionary relationship with Lygodium. In contrast, Coleoptera were underrepresented in our survey, but dominant in the fern programs and well represented in biological control of weeds as a whole (Julien and Griffiths, 1998). In the $P$. aquilinum program, Coleoptera were dominant, and 18 species were collected in Papua New Guinea alone (Kirk, 1977). Weevils were the key biological control agents for the two aquatic ferns (Forno, 1987; Hill, 1999). Our survey also shows the lack of any Hemiptera. Acanthuchus trispinifer (Hemiptera) can be found occasionally feeding on L. microphyllum, but it probably does not use the plant for reproduction. Some families of Hemiptera are not common on ferns such as Aleyrodidae (Mound and Halsey, 1978) or Psyllidae, which do not utilize them at all (Dave Hollis, London Museum of Natural History, London, UK, personal communication). Only a few species of Hemiptera were discovered in the other fern biological control programs, so the lack of these species on Lygodium is not surprising. One possible explanation for the high numbers of Hemiptera recorded from ferns Balik et al. (1978) could be that they use the fern as a refuge rather than as a true host.

Why were so few insect species collected from L. microphyllum? Weather conditions often play a part in insect abundance, but our collections were conducted over 3 years across all seasons, which should have minimized the effect of weather on species diversity. We did see a trend that populations tended to be higher following rain, but overall species diversity did not change. Comparison of nutrient levels in L. microphyllum leaf tissues between Australia and Florida may provide some insight. Preliminary sampling suggests that the Australian L. microphyllum contains approxi- 
mately $2 / 3$ as much nitrogen, phosphorous, and potassium as found in the Florida plants (Goolsby, unpublished data). Low nutrient levels, particularly low nitrogen in the Australian L. microphyllum, may account for the low density of insects. Insect herbivores, particularly chewing insects, have longer development times, and thus greater exposure to both abiotic and biotic mortality when feeding on nitrogen-poor plants (Mattson, 1980). This suggests that the high-nitrogen L. microphyllum plants in Florida may support larger populations of lepidopteran biocontrol agents than their low-nitrogen Australian host. The addition of nitrogen to target weeds has been used to promote establishment and impact of lepidopteran natural enemies used in biological control of weeds (White, 1993). Balik et al. (1978) analyzed several fern species from the state of Veracruz, Mexico for the presence of tannins and cyanogenic glycosides, compounds known to be effective deterrents of herbivory in temperate climates. All the fern species contained tannins, but only 3\% contained the cyanogenic glycosides, and the authors concluded that the compounds must not play a significant role as defensive compounds. Lygodium species probably have defense compounds, but we know of no studies that have investigated the presence or function of secondary plant defense compounds in Lygodium species. Another possible explanation for the low insect density could be the interaction between the eriophyid mite, $F$. perrepae, and the insect fauna. Mite-feeding appears to cause outbreaks of opportunistic fungi on the leaves, which causes premature senescence and leaf drop. Ovipositing insects may find the majority of the foliage on the mature stands of L. microphyllum to be unsuitable. Because the mite is nearly always associated with stands of the fern, an interaction of this sort could have a large-scale effect on insect herbivores. This effect could be relevant to multiple species releases. However, despite the low species richness as compared to higher plants, with intensive surveying we were able to detect a specialized fauna of some diversity, and importantly, natural enemies with biological control potential.

\subsection{Future directions}

The eriophyid mite, F. perrepae, should be given the highest priority as a biological control agent, based the damage it causes in the field and its potentially narrow host range. It is also the only herbivore that can be consistently collected in the field across all seasons and locations. Further, it is able to maintain populations in its native habitat a large suite of mite predators (Goolsby and Ozman, unpublished data). This would lead one to predict that this mite would be able to effectively deal with the predator complex in Florida, where L. microphyllum is invasive. The suite of leaf-feeding pyralid moths all appear to be narrowly specific, how- ever several Lygodium species from the Caribbean will need to be tested. Additionally, the risk to the temperate L. palmatum by these tropical/subtropical moths will need to be assessed. In a few cases, we have observed outbreak populations of these species and confirmed that they can cause considerable damage to L. microphyllum stands (Goolsby, unpublished data). In the absence of co-adapted natural enemies, these moths may cause sustained damage. However, many factors affect establishment and success of Lepidoptera in biological control programs. Dray et al. (2001) discuss these factors in their unsuccessful attempts to establish a Spodoptera pecticornis Hampson (Lepidoptera: Noctuidae) against waterlettuce (Pistia stratiotes L.) in Florida. The Callopistria spp., also belonging to Noctuidae, may face similar challenges. The stem-boring pyralid, Ambia sp., should also be given high priority because of the nature of the damage it inflicts on the plant. Minor amounts of feeding could cause large portions of the vining fern to die. Further, the concealed habitat of this pyralid may protect it from attack by non-specialized parasitoids. The sawfly, $N$. albicomus, should also receive attention because of its narrow field host specificity and its ability to pupate in the soil, which may increase survival after wildfires in south Florida. Future surveys should target Southern Africa and India. Although the preliminary molecular data indicated that African populations of the fern were not a good match with Florida, additional herbivores with potential as biological control agents might be found there. The west coast of southern India (Kerala) has a moderately good climatic match with Florida and like Africa it is geographically distant from the search areas described in this paper.

\section{Acknowledgments}

We greatfully acknowledge the following agencies for support of the research, USDA-ARS, Office of International Research Programs, Florida Department of Environmental Protection, and the South Florida Water Management District. The authors acknowledge the following valuable cooperators: Alma Solis (USDAARS, Systematic Entomology Laboratory, Washington, DC) and Shen-Horn Yen (Imperial College at Silwood Park. Ascot, UK) for descriptions and identification of Pyralidae, David Smith (USDA-ARS, Systematic Entomology Laboratory, Washington, DC) for identification of the sawfiles Martin Honey (London Museum of Natural History (NHM), London, UK) for identification of the Noctuidae; Danuta Knihinicki (New South Wales Agriculture, Orange, Australia) and Jan Boczek (Warsaw Agricultural University, Warsaw, Poland) for description of Floracarus perrepae; Ted Edwards (CSIRO Australian National Insect Collection (ANIC) Canberra, Australia) for identifying several species 
of Lepidoptera; Lawrence Mound (ANIC) for description of Octothrips lygodii; Graham Schultz (Northern Territory Department of Primary Industries, Darwin, Australia) and John Moulden (Western Australia Agriculture, Kununurra, Australia) for field assistance in northern Australia; staff of the Queensland Parks and Wildlife Department and Redlands Shire for access to field sites; G.S. Robinson (NHM) for identification of Callopistria spp. and information on fern-feeding Lepidoptera; Svatopluk Bily (Prague National Museum, Prague, Czech Republic) for identification of Endelus bakerianus; Bradley Brown, Jeff Makinson, and Ryan Zonneveld (CSIRO Entomology, Indooroopilly, Australia) for help with field-collecting and rearing of insects; Matthew Purcell (CSIRO Entomology) and Thai Van (USDA-ARS, Ft. Lauderdale, USA) for conducting initial collections in Vietnam; Gio Fichera, Dalio Mira, and Karryn Waterworth (CSIRO Entomology) for culture of test ferns in Australia; John Curran, Diana Hartley, Leslie McKensie, and Felice Driver (CSIRO Entomology) for the molecular diagnostics; John Trueman (Australian National University, Canberra, Australia) for molecular phylogenetic analysis; Luke Kasarjin (USDA-ARS, Ft. Lauderdale, USA) for acquisition of test ferns in Florida; Ted Center (USDAARS, Ft. Lauderdale) for encouragement and support of the biological control initiative for Old World climbing fern; M. So (Chinese Baptist College, Hong Kong, China), Patrick Lai (Hong Kong, Agriculture Forestry, and Conservation Dept.), Des and Azura Tsang (City University of Hong Kong) for facilitating Hong Kong surveys; Yutaka Arita (Mejio University, Nagoya, Japan) for identification of Musotima fuscolinealis; Tsukane Yamasaki (Tokyo Metropolitan University, Tokyo, Japan) for assistance with Japanese literature; Amporn Winotai (Thai Department of Agriculture, Bangkok, Thailand) for facilitating the surveys in Thailand; Ho Haw Leng and Tay Boon Liang (Kuala Lampur, Malaysia) for facilitating the surveys in Malaysia; staff of the Singapore National Parks for facilitating the surveys in Singapore; Hongyin Chen (USDA-Sino-American Biological Control Laboratory, Beijing, China) for facilitating the surveys in China; Jean Chazeau and Hervé Jourdan (Institut de recherche pour le dévelopement, Noumea, Nouvelle-Calédonie (France)) for facilitating surveys in New Caledonia; and B. Vasantharaj David and Alexander Jesudasan (Madras Christian College, Chennai, India) for facilitating surveys in India.

\section{References}

Balik, M.J., Furth, D.G., Cooper-Driver, G., 1978. Biochemical and evolutionary aspects of arthropod predation on ferns. Oecologia $35,55-89$.
Cathey, H.M., 1990. USDA Plant Hardiness Zone Map. USDA Miscellaneous Publication No. 1475, United States Department of Agriculture, Washington, DC.

Clausen, C.P., 1978. Introduced Parasites and Predators of Arthropod Pests and Weeds: A World Review. Agricultural Handbook No. 480, United States Department of Agriculture, Agricultural Research Service, Washington, DC.

DeBarro, P.J., Driver, F., Naumann, I.D., Clarke, G.M., Curran, J., 2000. Descriptions of three species of Eretmocerus Haldemann (Hymenoptera: Aphelinidae) parasitising Bemisia tabaci (Gennadius) (Hemiptera: Aleyrodidae) and Trialeurodes vaporariorum (Westwood)(Hemiptera: Aleyrodidae) in Australia based on morphological and molecular data. Aust. J. Entomol. 39, 259-269.

Dray Jr., F.A., Center, T.D., Wheeler, G.S., 2001. Lessons from unsuccessful attempts to establish Spodoptera pecticornis (Lepidoptera: Noctuidae), a biological control agent of waterlettuce. Biocontrol Sci. Technol. 11, 301-316.

Forno, I.W., 1983. Biological control of the floating weed, Salvinia molesta: exploratory studies of plant/insect interactions. Ph.D. Thesis, University of Queensland, Australia.

Forno, I.W., 1987. Biological control of the floating fern Salvinia molesta in north-eastern Australia: plant-herbivore interactions. Bull. Entomol. Res. 77, 9-17.

Garrison Hanks, J., 1998. A Monographic study of Lygodium Swartz (Pteridophyta: Lygodiaceae). Ph.D. Thesis, The New York University, New York, New York.

Hill, M.P., 1998. Herbivorous insect fauna associated with Azolla species (Pteridophyta: Azollaceae) in Southern Africa. Afr. Entomol. 6, 370-372.

Hill, M.P., 1999. Biological control of red water fern, Azolla filiculoides Lamarck (Pteridophyta: Azollaceae), in South Africa. In: Olckers, T., Hill, M.P. (Eds.), Biological Control of Weeds in South Africa (1990-1998). African Entomology Memoir, vol. 1, pp. 119-124.

Julien, M.H., Griffiths, M.W., 1998. Biological Control of Weeds: A World Catalogue of Agents and Their Target Weeds, fourth ed CAB International, Wallingford, UK.

Julien, M.H., Center, T.D., Tipping, P.W., 2002. Floating fern (Salvinia). In: Van Driesche, R., Blossey, B., Hoddle, M., Lyon, S., Reardon, R. (Eds.), Biological Control of Invasive Plants in the Eastern United States. US Forest Service Forest Health Technology Enterprise Team-2002-04, Morgantown, West Virginia, pp. 17-32.

Kirk, A.A., 1977. The insects associated with bracken fern, Pteridium aquilinum (L.) Kuhn in Papua New Guinea and their possible use in biological control. Master's Thesis, London University, UK.

Knihinicki, D.K., Boczek, J., 2002. New eriophyoid mites (Acari: Prostigmata: Eriophyoidea) from Australia. Int. J. Acarol. 28, 241-249.

Langland, K.A., Craddock Burks, K., 1998. Identification and Biology of Non-Native Plants in Florida's Natural Areas. University of Florida, Gainesville, USA.

Leibee, G.L., Stamps, R.H., 1999. Biology and management of the Florida fern caterpillar. Cut Foliage Grower 14, 1-4.

Mattson, W.J., 1980. Herbivory in relation to plant nitrogen content. Annu. Rev. Ecol. Syst. 11, 119-161.

Mound, L.A., Halsey, S.H., 1978. Whitefly of the World: A Systematic Catalogue of the Aleyrodidae (Homoptera) with Host Plant and Natural Enemy Data. British Museum (Natural History), Chichester, UK.

Mound, L.A., 2002. Octothrips lygodii sp. n. (Thysanoptera: Thripidae) damaging weedy Lygodium ferns in south-eastern Asia, with notes on other Thripidae reported from ferns. Aust. J. Entomol. 41, 216-220.

Pemberton, R.W., 1998. The potential of biological control to manage Old World climbing fern (Lygodium microphyllum), an invasive weed in Florida. Am. Fern J. 88, 176-182.

Pemberton, R.W., Ferriter, A.P., 1998. Old World climbing fern (Lygodium microphyllum), a dangerous invasive weed in Florida. Am. Fern J. 88, 165-175. 
Pemberton, R.W., Goolsby, J., Wright, T., 2002. Old World climbing fern (Lygodium microphyllum (Cav.) R. Br.). In: Van Driesche, R., Blossey, B., Hoddle, M., Lyon, S., Reardon, R. (Eds.), Biological Control of Invasive Plants in the Eastern United States. US Forest Service Forest Health Technology Enterprise Team-2002-04, Morgantown, West Virginia, pp. 139-147.

Robinson, G.S., Ackery, P.R., Kitching, I.J., Beccaloni, G.W., Hernandez, L.M., 2001. Host Plants of the Moth and Butterfly Caterpillars of the Oriental Region. The Natural History Museum and Southdene, Sdn. Bhd., Kuala Lumpur, Malaysia.

Room, P.M., Harley, K.L.S., Forno, I.W., Sands, D.P.A., 1981. Successful biological control of the floating weed Salvinia. Nature 294, 78-80.

Sands, D.P.A., 1983. Identity of the Cyrtobagous sp. (Coleoptera: Curculionidae) introduced into Australia for biological control of salvinia. J. Aust. Entomol. Soc. 22, 200.

Sands, D.P.A., Schotz, M., Bourne, A.S., 1986. A comparartive study on the intrinsic rates of increase of Cytrobagous singularis and $C$. salviniae (Coleoptera: Curculionidae) on the water weed Salvinia molesta. Entomol. Exp. Appl. 42, 231-237.

Smith, D.R., Wright, A.D., Winotai, A., Desmier de Chenon, R., 2002. Studies on Neostromboceros albicomus (Konow) (Hymenoptera: Tenthredinidae), a potential biological control agent for the Old World climbing fern, with notes on two other species of Neostromboceros. J. Hym. Res. 11, 142-151.

Sutherst, R.W., Maywald, G.F., Yonow, T., Stevens, P.M., 1999. CLIMEX. Predicting the Effects of Climate on Plants and Animals. CD-ROM and User Guide. CSIRO Publishing, Melbourne, Australia.

Thomson, J., 2000. Morphological and genomic diversity in the genus Pteridium (Dennstaedticeae). Ann. Bot. 85, 77-99.

White, T.C.R., 1993. The Inadequate Environment, Nitrogen and the Abundance of Animals. Springer-Verlag, Berlin, Germany.

Yoshiyasu, Y., 1985. A systematic study of the Nymphulinae and the Musotiminae of Japan (Lepidoptera: Pyralidae). Sci. Rep. Kyoto Prefect. Univ. 37, 1-162. 